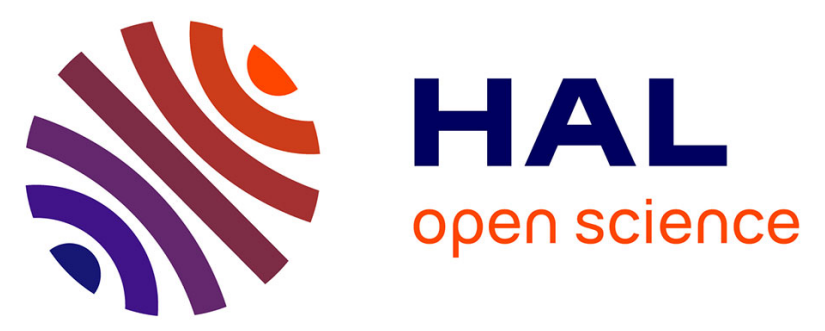

\title{
Performance efficiency of electro-coagulation coupled electro-flotation process (EC-EF) versus adsorption process in Doxycycline removal from aqueous solutions
}

S. Zaidi, T. Chaabane, V. Sivasankar, A. Darchen, R. Maachi, T. A. M. Msagati, M Prabhakaran

\section{To cite this version:}

S. Zaidi, T. Chaabane, V. Sivasankar, A. Darchen, R. Maachi, et al.. Performance efficiency of electro-coagulation coupled electro-flotation process (EC-EF) versus adsorption process in Doxycycline removal from aqueous solutions. Process Safety and Environmental Protection, 2016, 102, pp.450-461. 10.1016/j.psep.2016.04.013 . hal-01307762

\section{HAL Id: hal-01307762}

https://hal-univ-rennes1.archives-ouvertes.fr/hal-01307762

Submitted on 21 Jun 2016

HAL is a multi-disciplinary open access archive for the deposit and dissemination of scientific research documents, whether they are published or not. The documents may come from teaching and research institutions in France or abroad, or from public or private research centers.
L'archive ouverte pluridisciplinaire HAL, est destinée au dépôt et à la diffusion de documents scientifiques de niveau recherche, publiés ou non, émanant des établissements d'enseignement et de recherche français ou étrangers, des laboratoires publics ou privés. 


\section{$\underline{\text { Research highlights }}$}

- Doxycycline removal was achieved by EC - EF and adsorption treatment processes

- $\mathrm{Al}(\mathrm{OH})_{3}$ was the main player behind the removal of doxycycline in the two processes

- EC-EF process achieved $99 \%$ of doxycycline removal and for adsorption it was $73 \%$

v The adsorption of doxycycline improved from $95 \%$ to $99 \%$ due to the influence of $\mathrm{Ca}^{2+}$ 
Performance efficiency of electro-coagulation coupled electro-flotation process (EC - EF) versus adsorption process in Doxycycline removal from aqueous solutions

\section{S. Zaidi ${ }^{a}$, T. Chaabane ${ }^{a *}$, V. Sivasankar ${ }^{b}$, A. Darchen ${ }^{c}$, R. Maachi ${ }^{a}$,} T.A.M. Msagati ${ }^{\mathrm{d}}$, M. Prabhakaran ${ }^{\mathrm{e}}$

${ }^{\mathrm{a}}$ USTHB,FGM-GP/Environmental Department, BP 32 El-Alia 16111, Bab Ezzouar, Algiers, Algeria

${ }^{b}$ P.G. and Research Department of Chemistry, Pachaiyappa's College, Chennai - 600030 , Tamil Nadu, India

${ }^{\mathrm{c}}$ UMR CNRS n॰6226 Institut des Sciences Chimiques de Rennes, ENSCR, 11, Allée de Beaulieu, CS 50837 - 35708 Rennes Cedex 7, France

${ }^{\mathrm{d}}$ University of South Africa, College of Science Engineering and Technology, UNISA Science Campus, 1709 Roodepoort, Johannesburg, South Africa

${ }^{\text {e }}$ P.G. and Research Department of Botany, Pachaiyappa's College, Chennai - 600 030, Tamil Nadu, India

* Corresponding author email: tfkchaabane@yahoo.fr (T. Chaabane)

Tel. No. : +21321247169 


\section{Abstract}

Two treatment methodologies such as electro-coagulation coupled electro-flotation (EC $\mathrm{EF}$ ) and adsorption have been adopted to remove doxycycline hyclate (DCH) from the aqueous solution. An electro-coagulation (EC) coupled electro-flotation (EF) system has been designed in a closed reactor with a capacity of $1.5 \mathrm{~L}$ on a laboratory scale. Electro-synthesis of alumina (electro-generated alumina, EGA) using aluminium electrodes with magnesium chloride as an electrolyte was achieved and used for the adsorption experiments. In both the treatment techniques, removal of $\mathrm{DCH}$ efficiency as a function of $\mathrm{pH}$, initial $\mathrm{DCH}$ concentration and interfering electrolyte was studied. About $99 \%$ of DCH was removed at the end of 80 minutes in the range of $\mathrm{pH} 6-8$ by $\mathrm{EC}-\mathrm{EF}$ process whereas the adsorption technique achieved about $73 \%$ $\left(73 \mathrm{mg} \mathrm{g}^{-1}\right)$ of $\mathrm{DCH}$ removal in the $\mathrm{pH}$ range of $3-9$ at the equilibrium time of 150 minutes. Current density of $5.39 \mathrm{mS} \mathrm{cm}^{-2}$ and EGA dose of $4 \mathrm{~g} \mathrm{~L}^{-1}$ was optimized respectively for the EC - EF and adsorption processes. The presence of accompanying electrolyte $(\mathrm{NaCl})$ with $\mathrm{DCH}$ solution in the EC - EF process increased the electrical conductivity of $1.78 \mathrm{mS} \mathrm{cm}^{-1}$ and could achieve about $90 \%$ of DCH removal in the first 30 minutes. On the other hand, in the adsorption process, the participation of chloride $(\mathrm{NaCl})$ as an interfering ion decreased the $\mathrm{DCH}$ removal to about $76 \%$. Kinetic and isotherm models fitting the DCH removal dynamics in both the techniques have been checked for their validation. Characterization studies which include FTIR, SEM and XRD have also been done to explore the functional groups, surface morphology and crystalline nature of the solid materials.

Keywords : Electro-coagulation-floatation; Adsorption; Doxycycline Hyclate ; Models ; Characterization 


\section{Introduction}

Pharmaceutical compounds even at very low concentrations can cause serious environmental damages and of great exigency to develop some efficient and cost- effective treatment technologies to remove such compounds. These compounds, particularly the antibiotics and growth hormones affect the quality of soil (O'Connor and Aga, 2007), surface and groundwater (Chang et al., 2009; Tsai et al., 2010). Wan et al., 2010 reported that tetracycline is the second antibiotic in its production and usage across the world. Based on the report submitted by United States of Pharmacopeia (USP) Convention (1997) tetracycline causes a permanent discoloration of teeth, enamelhypoplasia and inhibition of skeletal growth in the fetus, infants and children up to 8 years of age. Doxycycline is a semi - synthetic form of tetracycline and an effective antibiotic against broad range of gram - positive, gram - negative and rickettsia. Due to its highly soluble nature, doxycycline exhibits high residual toxicity in surface and groundwater.

Various techniques for the tetracycline contaminated water are ozonation (Khan et al., 2010), Photo-Fenton process (Bautitz and Nogueira, 2007), photo electro-catalytic degradation (Liu et al., 2009), ion exchange (Wang et al., 2008) and adsorption (Reyes et al., 2006). Among the treatment processes, electro-coagulation has been reported to successfully treat wastewater containing fluoride (Khatibikamal et al., 2010), laundrywastewater (Janpoor et al., 2011), municipal wastewater (Al-Shannag et al., 2013), baker's yeast wastewater (Al-Shannag et al., 2014), Stronium (Kamaraj 2013), heavy metal ions (Al-Shannag et al., 2015) and electrocoagulation coupled to nano-filtration to treat wastewater containing metachlopramide was attempted by Chaabane et al. (2013). On the other hand, adsorption technique has also attracted the attention of researchers and includes the following adsorbents such as aluminum oxide (Chen et al. 2010), alumina (Zhao et al., 2015), goethite (Zhao et al., 2011; Zaho et al., 2014), montmorillonites (Zhao et al., 2012; Parolo et al. 2013; Chang et al., 2014) and palygorskite (Chang et al., 2009) for the treatment of tetracycline contaminated wastewater. Although tetracycline removal is of great concern, researchers have contributed less amount of work in the removal of doxycycline by adsorption using graphene-like layered molybdenum disulfide (Chao et al., 2014), activated charcoal (Afonne et al., 2002), activated sludge (Yang et al., 2005), Spent black tea leaves/pomegranate peel wastes (Hassan and Ali, 2014) and $\mathrm{Fe}_{3} \mathrm{O}_{4}$ magnetic 
nanoparticles (Ghaemi, 2014). Among the preferential adsorbents, aluminium oxide is of much interest as an adsorbent and has drawn attention in the treatment of water containing monothioarsenate (Xiao et al., 2015), dodecyl sulfate (Flilissa et al., 2014), fluoride (TchomguiKamga et al., 2013) and organic acids (Xiao-hong et al., 2007).

In continuance to our previous exploration on the removal of doxycycline by electro-coagulation coupled electro-flotation process (Sarah et al., 2015), the authors are interested to compare the efficiency of EC-EF process against the adsorption process using the electro-generated aluminium hydroxide.

\section{Experimental}

All reagents used in both the electro - chemical and adsorption processes are of analytical grade. The solutions were prepared using double distilled water. Doxycyclinehyclate [4S,4aR,5S,5aR,6R,12aR)-4-(dimethylamino)-1,5,10,11,12a －pentahydroxy-6-methyl-3,12dioxo-4a,5,5a,6-tetrahydro-4H-tetracene-2-carboxamidehydrochloride] was supplied by Sigma Aldrich, Germany and the structural formula is shown in Fig. 1 (inserted at the bottom left).

\subsection{Electro - coagulation coupled electro - flotation process}

The experimental setup is as follows:

A coupled EC/EF system in a closed reactor through continuous mode electrocoagulation (EC) was set up. The reactor capacity with the volume of $1.5 \mathrm{~L}$ was built at a laboratory scale (Fig. 1). In this electro-coagulation coupled electro-floatation (EC/EF) pilot setup, aluminium plates (as cathode and anode) of $11.9 \mathrm{~cm} \times 4.7 \mathrm{~cm} \times 0.4 \mathrm{~cm}$ dimension was designed to achieve the electro - coagulation process. The electro-flotation process was achieved using stainless steel anode and graphite cathode with dimensions of $11.0 \mathrm{~cm} \times 4.7 \mathrm{~cm} \times 1.0 \mathrm{~cm}$. The electrodes were connected to a digital DC supply (2303 GPS-type) with voltage and current range of $0-32 \mathrm{~V}$ and $0-4 \mathrm{~A}$ respectively. A digital ammeter and voltmeter were used to regulate the current and voltage. After each run of experiments, the used aluminium electrodes were rubbed with glass paper followed by immersion in $\mathrm{NaOH}$ solution of $0.1 \mathrm{M}$ for $10 \mathrm{~min}$. 
These electrodes were then rinsed with distilled water and dried at $105^{\circ} \mathrm{C}$ for $10 \mathrm{~min}$ before it is used for the next time. An ISMATEC (ISM 834C) peristaltic pump equipped with four channels is provided with Tygon ${ }^{\circledR}$ tubes of $0.8 \mathrm{~mm}$ internal diameter.

\subsection{Adsorption process}

\subsubsection{Electro-chemical synthesis of aluminium hydroxide (EGA)}

The electrolyte was hydrated magnesium chloride, $\mathrm{MgCl}_{2} \cdot 6 \mathrm{H}_{2} \mathrm{O}$. The electro-chemical setup was constituted with two parallel aluminum rectangular plates of dimensions $164 \times 29 \times 2$ cubic $\mathrm{mm}$ and $198 \times 40 \times 0.5$ cubic $\mathrm{mm}$ for anode and cathode respectively. The electrodes were washed prior to electrolysis experiments with $0.1 \mathrm{M} \mathrm{NaOH}$ and rinsed with distilled water and then dried in an air - oven at $105^{\circ} \mathrm{C}$ forlh. The space between electrodes was $1 \mathrm{~cm}$. The electrodes were immersed in a cell containing $0.1 \mathrm{~mol} \mathrm{~L}^{-1}$ electrolyte of $1 \mathrm{~L}$ (Tchomgui-Kamga et al., 2013) with magnetic stirring and controlled with an applied current of $0.7 \mathrm{~A}$ for $2 \mathrm{~h}$ using digital DC supply (2303 GPS type). At the end of the electrolysis, the wet mass of electro generated aluminium hydroxide (EGA) was collected after precipitation, dried at $105^{\circ} \mathrm{C}$ for 24 followed by rinsing with $200 \mathrm{~mL}$ of distilled water for about $1 \mathrm{~h}$ and again dried for at $105^{\circ} \mathrm{C}$ for 24h (Fig. 4B).

\subsubsection{Adsorption studies of DCH molecule onto EGA}

DCH solutions were prepared by diluting a home-made stock solution (200 $\left.\mathrm{mg} \mathrm{L}^{-1}\right)$.The adsorption of DCH experiments were carried out by the batch method at $25 \pm 3^{\circ} \mathrm{C}$ at $\mathrm{pH} 3.5 \pm 0.2$ for 240 min with an alumina dose of $1 \mathrm{gL}^{-1}$ at first and then with an optimized dose of $4 \mathrm{~g} \mathrm{~L}^{-1}$ for the influencing parameters such as $\mathrm{DCH}$ concentration, temperature and ionic strength.

The residual doxycycline hyclate (DCH) concentration was determined by UV - Visible spectrophotometer (Shimadzu UV - 1800, Japan) at a wavelength of $350 \mathrm{~nm}$ and by HPLC (hp HEWLETT series, PACKARD 1100). 


\subsection{Characterization of solids}

The $\mathrm{pH}$ of the point of zero charge $\mathrm{pH}_{\mathrm{PzC}}$ was measured by the so-called $\mathrm{pH}$ drift method (Newcombe et al., 1993). For this purpose, $0.05 \mathrm{~L}$ of a $0.01 \mathrm{M} \mathrm{NaCl}$ solution was placed in a jacketed titration vessel, thermostated at $298 \mathrm{~K}$, and $\mathrm{N}_{2}$ was bubbled through the solution to stabilize the $\mathrm{pH}$ by preventing the dissolution of $\mathrm{CO}_{2}$. The $\mathrm{pH}$ was then adjusted to successive initial values between 2 and 12, by adding either $\mathrm{HCl}$ or $\mathrm{NaOH}$ and the EGA $(0.1 \mathrm{~g})$ was added to the solution. The final $\mathrm{pH}$, reached after $48 \mathrm{~h}$, was measured and plotted against the initial $\mathrm{pH}$. The $\mathrm{pH}$ at which the final $\mathrm{pH}$ crosses the line $\mathrm{pH}_{\text {final }}=\mathrm{pH}_{\text {initial }}$ is taken as the $\mathrm{pH}_{\mathrm{PZC}}$ of the given EGA.

The wet solids after EC - EF and adsorption processes were dried at $110^{\circ} \mathrm{C}$ for about $5 \mathrm{~h}$ and then characterized by FTIR, SEM and XRD instrumental studies using FTIR spectrometer PerkinElmer (Version 10.03.06), X'Pert PRO X-ray diffractometer (PANalytical) and scanning electron microscope (JEOL, JSM-6360) respectively.

Models on reaction kinetics and isotherms validated with the DCH removal kinetics are detailed in Table 1.

\section{Results and discussion}

\section{1 (a) Effect of current density and time of electrolysis in EC-EF process}

The time of electrolysis and current density of electrochemical reactions determine the coagulant production rate and total production of coagulant respectively. From the applied current densities $\left(3.59 \mathrm{~mA} \mathrm{~cm}^{-2}-14.39 \mathrm{~mA} \mathrm{~cm}^{-2}\right)$, it is well accountable that the current density of $5.39 \mathrm{~mA} \mathrm{~cm}^{-2}$ was the optimum current density based on the maximum DCH removal and consumed time for electrolysis (Fig.2A). The removal of DCH was almost reached about 99\% after $80 \mathrm{~min}$. The residual DCH concentration was in the range $1.65-5.18 \mathrm{mg} \mathrm{L}^{-1}$. Although the DCH removal was remarkable with the residual DCH concentration of $0.53 \mathrm{mg} \mathrm{L}^{-1}$ at 14.39 $\mathrm{mAcm}^{-2}$, the consumption of current was 2.7 times higher with respect to the optimized current (current density $=5.39 \mathrm{~mA} \mathrm{~cm}^{-2}$ ) which leaves the residual DCH concentration of $0.76 \mathrm{mg} \mathrm{L}^{-1}$. The rate of DCH removal was directly proportional to current density because of the increased production of the coagulant ( $\mathrm{Al}^{3+}$ ions) at the anode. As a result of increased flocs generation 
rate, the DCH removal efficiency was enhanced. In other words, the higher the current density, the greater will be the generated flocs to trap the DCH molecules from the aqueous solution. After the time of electrolysis in the range of $50-60 \mathrm{~min}$, the residual DCH concentration was very low. The rate of its sorption onto the generated flocs at constant rate tends to decrease for a particular current density.

\section{1 (b) Effect of contact time in adsorption process}

The removal of DCH as a function of time reveals two different phases in the rate of DCH sorption onto EGA. For an adsorbent dose of $1 \mathrm{~g} \mathrm{~L}^{-1}$, the time of equilibrium established for the optimized $\mathrm{pH}$ of $3.5 \pm 0.5$ was $150 \mathrm{~min}(2 \mathrm{~h}$ and $30 \mathrm{~min})$ with the $\mathrm{DCH}$ removal of about $73 \%$. The time versus DCH removal plot depicts the initial DCH sorption took place at a rapid rate for the first 50 minutes (phase I) as a consequence of many available active sites on EGA surface and has shown about $62 \%$ of DCH removal. Phase II exhibited a gradual rate of DCH sorption and accounted only for about $11 \%$ removal of $\mathrm{DCH}$.

\subsection{Effect of pH}

(a) EC-EF process

The $\mathrm{pH}$ of any electrolyte drives the fate of electro-coagulation process (Yavuz et al., 2011). The $\mathrm{pH}$ of the electrolytic medium increases during the flocculation - sorption phase and gets stabilized in the $\mathrm{pH}$ range $7.52-7.91$ for various initial $\mathrm{DCH}$ concentrations at an initial $\mathrm{pH}$ of 7.0 as reported by Yavuz et al., (2011). The associated increase in pH may be corroborated due to the electrolysis of water leading to hydrogen evolution and $\mathrm{OH}^{-}$production (Malakootian et al., 2010). The relative stability of $\mathrm{pH}$ after the process could be ascertained due to the formation of sweep $\mathrm{Al}(\mathrm{OH})_{3}$ flocs with less solubility in the range of $\mathrm{pH} 6-8$ (Emamjomeh and Sivakumar, 2009). The effect of $\mathrm{pH}$ on DCH removal is shown in Fig. 2B. The removal of DCH at different $\mathrm{pH}$ values of $6.03,7.04,7.52$ and 8.02 was conducted with the initial DCH concentration of $100 \mathrm{mg} \mathrm{L}^{-1}$. The removal of $\mathrm{DCH}$ was achievable about $99 \%$ in the $\mathrm{pH}$ range 6.03 - 8.02. Similar observation was experienced in the study of boron removal by Ezechi et al., (2014).

The main reactions which take place during electro-coagulation at the two electrodes are:

At Anode: $\mathrm{Al} \rightarrow \mathrm{Al}^{3+}+3 \mathrm{e}$

At Cathode: $2 \mathrm{H}_{2} \mathrm{O}+2 \mathrm{e} \rightarrow \mathrm{H}_{2}(\mathrm{~g})+2 \mathrm{OH}^{-}$ 
Under acidic condition $(\mathrm{pH}<3.3)$ due to protonation, the cationic form of $\mathrm{DCH}(+00)$ develops the electrostatic repulsion with predominant cationic monomers of $\mathrm{Al}^{3+}$ and $\mathrm{Al}(\mathrm{OH})^{2+}$ and lessens the removal efficiency of DCH (Ouaissa et al., 2014). The possibility of DCH speciation at various $\mathrm{pH}$ values (Zhang et al., 2011) as zwitterion $( \pm 0)$ was due to the loss of proton from the phenolic diketone moiety. On the other hand, the $\mathrm{pH}$ between 6.03 and 8.02 generates $\mathrm{Al}^{3+}$ and $\mathrm{OH}^{-}$ions to form various monomers such as $\mathrm{Al}(\mathrm{OH})_{2}{ }^{+}, \mathrm{Al}(\mathrm{OH})_{2}{ }^{2+}$ and other polymeric species such as $\mathrm{Al}_{6}(\mathrm{OH})_{15}{ }^{3+}, \mathrm{Al}_{7}(\mathrm{OH})_{7}{ }^{4+}, \mathrm{Al}_{13}(\mathrm{OH})_{34}{ }^{5+}$ were finally converted into the insoluble amorphous $\mathrm{Al}(\mathrm{OH})_{3}(\mathrm{~s})$ through complex polymerization/precipitation kinetics (Merzouk et al., 2009). The formation of $\mathrm{Al}(\mathrm{OH})_{3}(\mathrm{~s})$ is therefore optimal in the 4-9 $\mathrm{pH}$ range. In addition, the cathode ( $\mathrm{Al}$ ) may be chemically attacked by $\mathrm{OH}^{-}$ions generated together with $\mathrm{H}_{2}$ at high $\mathrm{pH}$ values as:

$2 \mathrm{Al}+6 \mathrm{H}_{2} \mathrm{O}+2 \mathrm{OH}_{-} \rightarrow 2 \mathrm{Al}(\mathrm{OH})_{4}{ }^{-}+3 \mathrm{H}_{2}$

However, the $\mathrm{pH}$ affects also the bubble size (Glembotskii et al., 1975). Typical bubble sizes in electro-coagulation always fall in the range of 20-70 $\mu \mathrm{m}$ (Adhoum et al., 2004). They are far smaller than those observed in conventional air-assisted floatation, which provides both sufficient surface area for gas-liquid-solid interfaces and mixing efficiency to favor the aggregation of tiny destabilized particles. Hydrogen bubbles, which usually obey to a lognormal size distribution, are also known to be the smallest at about neutral pH (Fukui and Yuu 1985). The best removal of DCH could be accomplished by charge neutralization and sorption in the presence of the constituent monomers and polymers.

\section{(b) Adsorption process onto EGA}

The $\mathrm{pH}_{\mathrm{pzc}}$ of EGA was determined to be $7.8 \pm 0.1$ and is able to develop a surface with positively charged ions. The optimized $\mathrm{pH}$ of $3.5 \pm 0.05$ with high $\mathrm{DCH}$ removal efficiency of about $73 \%$ was achieved at the end of 150 minutes (Fig. 3A). Nevertheless, the $\mathrm{pH}$ range of $3-8$ was quite suitable for DCH removal of at least $73 \%\left(73 \mathrm{mg} \mathrm{g}^{-1}\right)$ using EGA with an adsorbent dose of $1 \mathrm{~g}$ $\mathrm{L}^{-1}$. Conversely in the $\mathrm{pH}$ range of $9-12$, the removal of $\mathrm{DCH}$ falls down to $40 \%$. This descending tread may be attributed to the fact that the decrease in the density of surface dispersed positive charge (where $\mathrm{pH}>\mathrm{pH}$ pzc) as witnessed from the value of $\mathrm{pH}_{\mathrm{pzc}}$. Very poor amount of DCH sorption of about $12 \mathrm{mg} \mathrm{g}^{-1}$ onto EGA was registered at $\mathrm{pH} 2$. 


\section{(c) Alumina and DCH affinity}

The acquired surface positive sites with large surface area on the amorphous structure of hydrolyzed $\mathrm{Al}(\mathrm{OH})_{3}$ makes the viability of sorption with the macro-molecular organic $\mathrm{DCH}$ anions rather existing as a free hydrated metal ion (Zhou et al., 2008). It is also envisaged that the $\mathrm{DCH}$ at basic conditions prevails as either a mono valent or a divalent anion due to deprotonation of tricarbonyl system and phenolic diketone moiety. As a consequence, high removal of DCH may be associated, due to the attractive force between the positive aluminium and negative $\mathrm{DCH}$ ions, and hence the sorption of the latter onto $\mathrm{Al}(\mathrm{OH})_{3}$ in $\mathrm{EC}-\mathrm{EF}$ process and EGA from adsorption process. The active flocs resulting from EC - EF process facilitate the rapid sorption of soluble $\mathrm{DCH}$ compound by colloidal $\mathrm{Al}(\mathrm{OH})_{3}$ particles and ultimately get separated from the aqueous medium by sedimentation or hydrogen floatation as reported by Ghernaout et al., 2009).

\subsection{Effect of initial DCH concentration}

(a) EC-EF process

The initial concentration provides an important driving force to overcome all mass transfer resistance of solutes between the aqueous and the solid phase (Ji et al., 2009). The removal efficiency of DCH as a function of initial DCH concentration at $5.39 \mathrm{~mA} \mathrm{~cm}^{-2}$ is shown in Fig. 2C. The percentage of DCH removal was decreased with respect to the increase in the initial concentration and could easily be distinguishable up to $50 \mathrm{~min}$. But after $50 \mathrm{~min}$, the residual DCH concentration falls between $2.3 \mathrm{mg} \mathrm{L}^{-1}$ and $2.6 \mathrm{mg} \mathrm{L}^{-1}$. As per Faraday's law, at a constant current density, the generated aluminium flocs for a particular time remain constant for various DCH concentrations $\left(60-180 \mathrm{mg} \mathrm{L}^{-1}\right)$. But the requirement of aluminium flocs will be greater for the higher DCH concentration and hence becomes insufficient to capture the extra organic DCH species. Evidently single, smooth and continuous graphical curves leading to saturation which suggests the monolayer coverage of $\mathrm{DCH}$ on the surface of $\mathrm{Al}(\mathrm{OH})_{3}$ was reported (Lakshmi et al., 2013).

\section{(b)Adsorption process onto EGA}

Based on the dose optimization, $4 \mathrm{~g} \mathrm{~L}^{-1}$ of EGA at a $\mathrm{pH}$ of $3.5 \pm 0.05$ was used to study the removal of $\mathrm{DCH}$ as a function of $10 \mathrm{DCH}$ concentrations in the range of $5-190 \mathrm{mg} \mathrm{L}^{-1}$. The graph (Fig. 3B) shows an increase from about $94 \%$ to $98 \%$ with small increments between the 
initial DCH concentrations of $5 \mathrm{mg} \mathrm{L}^{-1}$ and $40 \mathrm{mg} \mathrm{L}^{-1}$. After this, low decrements were observed with a DCH removal difference of about $8 \%$ for $50 \mathrm{mg} \mathrm{L}^{-1}, 60 \mathrm{mg} \mathrm{L}^{-1}$ and $100 \mathrm{mg} \mathrm{L}^{-1}$. The percentage removal falls further towards $77 \%$ for the DCH concentration of $190 \mathrm{mg} \mathrm{L}^{-1}$. The initial rise in the $\mathrm{DCH}$ removal for the initial concentration from $5 \mathrm{mg} \mathrm{L}^{-1}$ to $40 \mathrm{mg} \mathrm{L}^{-1}$ may be ascribed to the excess availability of active sites on the surface of EGA leading to an incremental uptake of DCH species. But the availability of active sites becomes exhausted and reduced the uptake of DCH molecules and hence the graph (red colored) falls down to a minimum percentage. High intermolecular competitiveness to occupy the available lower energetic surface sites on EGA as witnessed by Sivasankar et al., (2013). The sorption capacity (blue colored graph) of EGA initially increases to a maximum and becomes consistent (not shown in the graph) may be due to the presence of excess fluoride than the active sites on EGA.

\subsection{Effect of interfering ions}

(a) EC-EF process

In order to increase the conductivity of wastewater due to resistance between the electrodes, the addition of sodium chloride was suggested during electro coagulation process.

Researchers used sodium chloride to increase the conductivity of the solution nevertheless, sodium nitrate and sodium sulfate were also used as electrolytes (Aber et al., 2009).On increasing the salt concentration, the power consumption of electrolytic cells is reduced due to the reduction in cell voltage at constant current density (Kashefialas et al., 2006). Although the type of electrolyte has no effect in favor of the removal efficiency, it provides the pronounced effect on cell voltage and current consumption during the EC process. It is also reported that at high anode potential, direct oxidation of organic compounds or $\mathrm{H}_{2} \mathrm{O}$ may also take place (Ge et al., 2004). The influence of sodium chloride was remarkable in facilitating the removal of DCH, whereas the influence of sodium nitrate and potassium chlorides were alike and their effect on the removal of DCH was almost closer to each other. The inter-wined curves shown in Fig. 2D illustrates that no appreciable influence was observed due to the addition of sodium nitrate and potassium chlorides. The average electrical conductivity of DCH electrolyte in the presence of sodium chloride was recorded to be $1.78 \mathrm{mS} \mathrm{cm}$. The electrical conductivity of the DCH electrolyte in the presence of $\mathrm{KCl}$ and $\mathrm{NaNO}_{3}$ was recorded as $1.45 \mathrm{mS} \mathrm{cm}{ }^{-1}$ and $1.22 \mathrm{mS} \mathrm{cm}{ }^{-1}$ respectively. Hence it is apparent that high conductivity of the EC system due to $\mathrm{NaCl}$ enables 
the DCH removal of about $90 \%$ at the end of $30 \mathrm{~min}$ but for the other salts $\left(\mathrm{KCl}\right.$ and $\left.\mathrm{NaNO}_{3}\right)$ the same percentage of removal could be achieved after $60 \mathrm{~min}$. From the above observations, it is quite understood that half of the power is expendable to achieve $90 \%$ removal of DCH in the presence of sodium chloride as compared to the other potassium chloride and sodium nitrate as supporting electrolytes. The influence of nitrate in other forms as nitrite, ammonia and nitrogen (Murphy, 1991) becomes inappropriate because the working $\mathrm{pH}$ is 7 and the reduction of nitrate due to aluminium is impossible. Evidently, the range of $\mathrm{pH} 6.38-7.63$ indicated that there may be no ejection of hydroxide ions as a result of nitrate reduction. Hence in the binary system containing DCH and nitrate, the influence of nitrate as such to the DCH removal is taken into consideration.

\section{(b) Adsorption process}

The decrease in the percentage removal of $\mathrm{DCH}$ or sorption inhibition to $\mathrm{DCH}$ molecules onto EGA due to the presence of other ions is represented in Fig. 3C. It can be illustrated that the accompanying anions such as nitrate, chloride and sulfate $\left(0.25-10.0 \mathrm{~g} \mathrm{~L}^{-1}\right)$ lessened the percentage removal of $\mathrm{DCH}$ to about $81 \%, 76 \%$ and $35 \%$ respectively. Among the competing anions, the inhibiting potential can be observed in the following order:

\section{Sulfate $>$ Chloride $>$ Nitrate}

The inverse proportionality between DCH removal and anionic concentration with respect to each other is quite evident from the experimental studies. It could be deemed as a severe competition between the sulfate and DCH molecules which ultimately prefer the cationic/active sites of EGA as the consequence is evident from the inhibition up to about $35 \%$. The other anions such as chloride and nitrate accompanying the DCH molecules were determined with a percentage difference of about $22 \%$ and $16 \%$ respectively. On the other hand, the electrolyte containing calcium and chloride was found to have greater impact on the removal of DCH molecules. Initially, the sorption of DCH molecules onto EGA during the absence of $\mathrm{Ca}^{++}$and $\mathrm{Cl}^{-}$was about $94.09 \%$ but its company with $\mathrm{DCH}$ in aqueous solution enhanced the removal of DCH molecules to $94.77 \%$ for $0.25 \mathrm{~g} \mathrm{~L}^{-1}$ to $98.52 \%$ for $2 \mathrm{~g} \mathrm{~L}^{-1}$ and remains almost constant up to $10 \mathrm{~g} \mathrm{~L}^{-1}$. The increase was based on the cationic $\left(\mathrm{Ca}^{2+}\right)$ influence and gets increased further with respect to an increased addition. This increase in adsorption of DCH species (containing electron 
rich sites) may be attributed to the increase in surface positive charges which help to attract negatively charged sites of DCH onto various metal oxide surfaces. Similar observations for various other anions have been reported (Maliyekkal et al., 2010).

\subsection{Validation of adsorption kinetics in EC - EF and adsorption processes}

The study on adsorption kinetics is significant because it provides valuable insight into the reaction pathway and the corresponding sorption mechanism. The sorption mechanism depends on the physical and chemical characteristics of the adsorbent and also on the masstransfer process. The kinetic data (Table 2 and Table 3 ) resulted from experiments were checked for the maximum fit with the kinetic models (pseudo - first - order, pseudo - second - order, intra - particle diffusion and elovich) and isotherm models shown in Table 4 (Langmuir, Freundlich and DKR).

The dynamics of $\mathrm{DCH}$ sorption onto $\mathrm{Al}(\mathrm{OH})_{3}$ at an optimized $\mathrm{pH}(7.02)$ with respect to different inter - electrode distance, initial DCH concentrations, supporting electrolytes and flow rate was validated using kinetic models such as pseudo - first - order, pseudo - second - order, intra - particle diffusion and elovich models.

Based on pseudo - first - order and pseudo - second - order models, it is possible to elucidate the mechanism (of adsorption) and potential rate controlling steps (Chutia et al., 2009) of DCH sorption onto $\mathrm{Al}(\mathrm{OH})_{3}$ particles and $\mathrm{EGA}$ in $\mathrm{EC}-\mathrm{EF}$ and adsorption processes respectively.

Pseudo - first - order model is a simple adsorption kinetic model (eqn.1), suggested by Lagergen (1898) and further referred by Ho et al., (1996) is unable to apply throughout the range of contact time.

According to pseudo-second-order kinetics (eqns. 2 and 3), the rate of adsorption is directly proportional to the number of active sites on the adsorbent surface. An excellent compliance of the pseudo - second - order model seems appreciable with the regression coefficients of range $0.987-0.999$ and $0.999-1.000$ respectively for EC - EF and adsorption processes. Based on the regression values, it may be ascertained that the pseudo - second - order was more validated than that of the pseudo - first - order model in both the processes.

It is inferred from the Weber-Morris intra-particle diffusion plot (eqn. 4) that the initial curved portion reflects the film or boundary layer diffusion effect and the subsequent linear 
portion (plateau) depicts the intra-particle diffusion effect. The graphical plots deviate from passing through the origin and this deviation may be caused due to the difference between the rate of mass transfer in the initial and final stages of molecular binding and the resulting complex mechanism. The mechanism incorporates surface adsorption and intra-particle diffusion to the rate determining step. The thickness of boundary layer, determined from the intercept value $\mathrm{C}$ is inversely proportional to the external mass transfer. The value of $\mathrm{C}$ seems to be very sensitive with respect to the change in initial $\mathrm{DCH}$ concentration and supporting electrolyte. The regression values indicate the intra - particle diffusion model did not fit satisfactorily with the DCH sorption onto aluminium hydroxide flocs resulting from EC-EF process. Unlike the EC EF process, this model fits fairly well with the variation of rate constant $\left(\mathrm{k}_{\mathrm{i}}\right)$ value in the range $0.622-0.593 \mathrm{mg} \mathrm{g}^{-1} \min ^{-0.5}$.

Elovich model (eqn. 5) is one among the useful kinetic models for describing chemisorption (Aharoni and Tompkins, 1970). The calculated values of initial adsorption rate (A) and constant of desorption (B) with corresponding regression coefficients indicated that the Elovich model fits fairly well with the dynamics of $\mathrm{DCH}$ sorption onto grown flocs of $\mathrm{Al}(\mathrm{OH})_{3}$ in the $\mathrm{EC}-\mathrm{EF}$ process. On the other hand, the Elovich constants A and B, derived from the adsorption process was almost the same and indicate that the increment in temperature causes little changes to the Elovich parameters. The $\mathrm{R}^{2}$ values did not fit as good for sorption process as that of EC - EF process.

\subsection{Validation of Adsorption isotherms in EC - EF and adsorption processes}

Equilibrium data can be analyzed using well known adsorption isotherms such as Langmuir and Freundlich isotherms, which provide the basis for the design of adsorption systems.

The Freundlich model (Eq. 7) is based on the sorption which takes place on a heterogeneous phase and is chosen as an indirect evidence for site heterogeneity and /or surface heterogeneity. The model makes an assumption that the energy distribution of sorption sites decays exponentially.

The degree of non - linearity between DCH in solution and EGA adsorbed DCH is indicated by the value of $n$ as 1.912 . The value of $1 / n$ predicts the nature of sorption to be normal $(1 / \mathrm{n}<1)$ and a joint measure of both the relative magnitude and diversity of energies 
associated with a particular sorption process [Karickhoff, 1981; Weber et al., 1992]. The DCH sorption capacity $\left(\mathrm{K}_{\mathrm{F}}\right)$ of $27.73 \mathrm{mg} \mathrm{g}^{-1}$ was recorded based on the variation in the initial $\mathrm{DCH}$ concentration at $288 \mathrm{~K}$. The corresponding heterogeneity of surface $(1 / \mathrm{n})$ was 0.523 with a poor $\mathrm{R}^{2}$ value of 0.766 .

Langmuir model considers that the sorption energy of each molecule is the same which is independent of the surface of the adsorbent. According to Langmuir model (Eq. 6), the amount of fluoride adsorbed onto EGA was $166.67 \mathrm{mg} \mathrm{g}^{-1}$ with the corresponding Langmuir isotherm constant of $0.214 \mathrm{~L} \mathrm{mg}^{-1}$. The feasibility of Langmuir isotherm can be expressed in terms of a dimensionless constant or equilibrium parameter, $\mathrm{R}_{\mathrm{L}}$ which is equal to $\left[1 /\left(1+\mathrm{b} \mathrm{C}_{0}\right)\right]$. The data of dimensionless constant was in the range $0.024-0.479$ for the varied initial DCH concentrations and ascertains the favorable nature of sorption onto EGA. Langmuir and Freundlich isotherms become invalidated with the $\mathrm{DCH}$ removal kinetics run by $\mathrm{EC}-\mathrm{EF}$ process and hence the data are not represented.

Dubinin-Radushkevich (D-R) isotherm is more general than Langmuir isotherm owing to its disagreement for a homogenous surface or a constant adsorption potential. Using D-R equations (Eqs. 8-10) with reference to $\mathrm{EC}-\mathrm{EF}$ and adsorption processes, the constant $\beta$ gives the free energy, $\mathrm{E}\left(\mathrm{kJ} \mathrm{mol}^{-1}\right)$ for the transfer of $1 \mathrm{~mol}$ of fluoride from infinity to the surface of generated $\mathrm{Al}(\mathrm{OH})_{3}$ flocs (in EC - EF process) and EGA (in adsorption process). The magnitude of $\mathrm{E}$ is helpful in understanding the nature of adsorption. The recorded value of $\mathrm{E}$ in the adsorption process was determined to be $1.582 \mathrm{~kJ} \mathrm{~mol}^{-1}$ for the effect of initial DCH concentration at a constant temperature of $288 \mathrm{~K}$. It is very apparent that the value of $\mathrm{E}$ is less than $8 \mathrm{~kJ} \mathrm{~mol}^{-1}$ and ascertained the nature of DCH sorption by physical forces (Swain et al., 2009). On the other hand, the value of $\mathrm{E}$ is equal to $7.905 \mathrm{~kJ} \mathrm{~mol}^{-1}$ for initial $\mathrm{DCH}$ concentration as a variable at a constant temperature with the monolayer capacity $\left(\mathrm{q}_{\mathrm{m}}\right)$ of 299.5 $\mathrm{mg} \mathrm{g}^{-1}$ and fairly supported with the $\mathrm{R}^{2}$ value of 0.947 . The value of $E$ suggested the possibility of dominant chemical forces (Swain et al., 2009) between $\mathrm{DCH}$ and $\mathrm{Al}(\mathrm{OH})_{3}$ flocs.

The $\mathrm{R}^{2}$ values of the above isotherms for the adsorption of DCH onto EGA are in the following order : Langmuir $>$ DKR $>$ Freundlich. 


\subsection{Characterization studies}

The material after the EC/EF process was characterized for FTIR, SEM and XRD studies. The assignments of Fourier Transform IR study which occur at different frequencies are shown in Table 5. The broadband appears between $3500 \mathrm{~cm}^{-1}$ and $3000 \mathrm{~cm}^{-1}$ with an assignment of $3307.56 \mathrm{~cm}^{-1}$. This displacement was due to the displacement of $\mathrm{OH}$ band by overlapping of hydrogen bonds and the superimposition of $\mathrm{NH}$ band. The absence of $>\mathrm{C}=\mathrm{O}$ stretching frequency $\left(>\mathrm{C}=\mathrm{O}\right.$ at $1715 \mathrm{~cm}^{-1}$;- $\mathrm{COOH}$ between $\left.1700-1730 \mathrm{~cm}^{-1}\right)$ may be associated due to the newly formed bond between carbonyl oxygen of $\mathrm{DCH}$ and aluminium ions (as $>\mathrm{C}-\mathrm{O}-\mathrm{Al}$ ).

The $\mathrm{X}-$ Ray diffraction patterns (Fig. 4D) for $\mathrm{DCH}$ and $\mathrm{DCH}$ adsorbed $\mathrm{Al}(\mathrm{OH})_{3}$ illustrate the amorphous and crystalline merged amorphous patterns respectively. The narrow diffraction peaks at $18.8^{\circ}, 20.3^{\circ}, 27.9^{\circ}, 40.3^{\circ}$ and $53.2^{\circ}$ are assigned to bayerite (PDF No. 20-11). The retained amorphous pattern of $\mathrm{DCH}$ is perturbed with the overlapping crystalline pattern due to the $\mathrm{DCH}$ adsorbed polymorph, $\mathrm{Al}(\mathrm{OH})_{3}$. In support of the present study, it was reported that the formation of bayerite was predominant at near neutral $\mathrm{pH}(\mathrm{pH} \geq 7)$ and higher $\mathrm{pH}$ values (Carrier et al., 2007). The amorphous or slightly crystalline nature of electro - generated aluminium hydroxides and oxo-hydroxides was remarkable because of the very slow crystallization process. Hence the reflections of Bragg showing very broad bumps with low intensity for the phases were analyzed at short distances (Drouiche et al., 2009).

On the other hand, crystallinity of EGA can be observed from Fig. 4A along with the display of amorphous nature through broad peaks of the pattern. Complex forms of alumina oxides along with the exhibition of impregnated magnesium compounds are well observed from the demonstrated peaks of XRD pattern. Similar observation was reported (Teng - Shih and Zin - Bou Liu, 2006) with the formation of complex oxides of aluminium. As there was no appreciable change, the XRD pattern of DCH adsorbed EGA is not represented.

The scanning electron micrograph for $\mathrm{Al}(\mathrm{OH})_{3}$ material (Fig. 4D) resulted after EC - EF treatment shows that the aluminium floc - bound DCH material was at greater heterogeneity with irregular, sharp edged particles and exposing a rough surface. The precipitated grains constitute the distinguished geometries and make the formed aggregates with no well defined structural pattern. The Electro-generated Alumina (EGA) was observed with heterogenous surface. The EDAX analysis has shown that EGA contains the following elements such as Al (39.4\%), Mg (10.3\%), O (35.9\%) and $\mathrm{Cl}(13.4 \%)$. The surface morphology of EGA particles 
(Fig. 4C) can be evidenced with irregular shaped with almost blunt phases. The agglomeration of particles leading to the formation of a bigger sized particle with no perfect shape can also be visualized. These asymmetric EGA particles seem to appear rough and porous. The surface morphology of DCH loaded EGA (not shown) resembles that of the virgin EGA.

\section{Concluding remarks}

The EC - EF treatment process yielded an efficiency of about $99 \%$ whereas the adsorption process of about $73 \%$. The participation of sodium chloride as a supporting electrolyte in the EC - EF system halved the power consumption as a result of the increased electrical conductivity to $1.78 \mathrm{mS} \mathrm{cm} \mathrm{cm}^{-2}$ and in addition that $\mathrm{NaCl}$ enabled the $\mathrm{DCH}$ removal in the first 30 minutes. The simultaneously focused adsorption process with EGA as an adsorbent was able to remove the $\mathrm{DCH}$ molecules by about $4 \%$ when calcium chloride was used as the accompanying electrolyte. Conversely the binary system containing DCH and sodium sulphate could be declared to be the worst environment where the sulphate ions poisoned the pace of the DCH sorption onto EGA. Pseudo - second - order model was in good compliance than that of pseudo - first - order model for both the removal techniques. The corroboration of DKR model in favour of dominant chemical forces than physical forces in EC - EF system but the reverse was judged in the sorption process by EGA. Langmuir and Freundlich isotherms did not support the DCH removal dynamics in EC - EF process but they provide a good validation for the sorptive removal of DCH by EGA. FTIR study corroborated the formation of new bonds between carbonyl oxygen (of DCH molecules) and aluminium ions (of flocs) in the EC - EF process. X - Ray diffraction study confirmed that the EC - EF grown aluminium flocs corresponds to the bayerite pattern whereas EGA was investigated to contain mixed aluminium oxides. The morphological pattern ascertained that the surface of the EC - EF generated solid was highly heterogeneous and irregular with precipitated grains. In the case of EGA, agglomerated and asymmetric particles with blunt phases are plenty with rough and porous morphology.

\section{Acknowledgement}

In completing this modest contribution of research, I would like to thank the Heads of the collaborating educational institutes' namely National College of Chemistry, Rennes top (France), 
Research Department of Chemistry, Pachaiyappa's College, Chennai, India \&University of Science and Technology HouariBoumediene Algiers (Algeria) and P.G.

\section{References}

Aber, S., Amani-Ghadim, A.R., Mirzajani, V., 2009. Removal of Cr(VI) from polluted solutions by electrocoagulation: Modeling of experimental results using artificial neural network. J. Hazard. Mater. 171, 484-490.

Adhoum, N., Monser, L., Bellakhal, N., Belgaied, J., 2004. Treatment of electroplating wastewater containing $\mathrm{Cu}^{2+}, \mathrm{Zn}^{2+}$ and $\mathrm{Cr}(\mathrm{VI})$ by electrocoagulation. J. Hazard. Mater. B 112, 207-213.

Afonne, O.J., Orisakwe, O.E., Ofuefule, S.I., Tsalha, S., Obi, E., Ilondu, N.A., Okorie, O., 2002. Saline cathartics and adsorptive capacity of activated charcoal for doxycycline, Acta Pol. Pharm.-Drug Res. 59, 177-180.

Aharoni, C., Tompkins, F.C., 1970. Kinetics of Adsorption and Desorption and the Elovich Equation, in: D.D. Eley, P. Pines, P.B. Weisz (Eds.), Advances in Catalysis and related subjects, vol. 21, Academic Press, New York.

Bautitz, I.R., Nogueira, R.F.P., 2007. Degradation of tetracycline by photo-Fenton process - solar irradiation and matrix effects. J. Photochem. Photobiol. A. 187, 33-39.

Carrier, X., Marceau, E., Lambert, J.-F., Che, M., 2007. Transformations of $\gamma$-alumina in aqueous suspensions: 1. Alumina chemical weathering studied as a function of pH.J. Colloid Interface Sci. 308, 429-437.

Chang, P.-H., Jean, J.-S., Jiang, W.-T., Li, Z., 2009. Mechanism of tetracycline sorption on rectorite. Colloids Surf. A: Physicochem. Eng. Asp. 339, 94-99.

Chang, P.-H., Li, Z., Yu, T.-L., Munkhbayer, S., Kuo, T.-H., Hung, Y.-C., Jean, J.-S., Lin, K.-H., 
2009. Sorptive removal of tetracycline from water by palygorskite. J Hazard. Mater. 165, $148-155$.

Chang, P.-H., Li, Z., Jiang, W.-T., Kuo, C.-Y., Jean, J.-S., 2014. Adsorption of tetracycline on montmorillonite: influence of solution $\mathrm{pH}$, temperature, and ionic strength, Desalination and Water Treatment, DOI: 10.1080/19443994.2014.924881.

Chao, Y., Zhu, W., Wu, X., Hou, F., Xun, S., Wu, P., Ji, H., Li, H., 2014. Application of graphene-like layered molybdenum disulfide and its excellent adsorption behaviour for doxycycline antibiotic. Chem. Engg. J 243, $60-67$.

Chen, W.-R., Huang, C.-H., 2010. Adsorption and transformation of tetracycline antibiotics with aluminum oxide, Chemosphere, 79, 779-785.

Chutia, P., Kato, S., Kojima, T., Satokawa, S., 2009. Arsenic adsorption from aqueous solution on synthetic zeolites. J. Hazard. Mater. 162, 440-447.

Drouiche, N., Aoudj, S., Hecini, M., Ghaffour, N., Lounici, H., Mameri, N., 2009. Study on the treatment of photovoltaic wastewater using electro-coagulation fluoride removal with aluminum electrodes characteristics of productions. J. Hazard. Mat. 169, 65-69.

Dubinin, M.M., Radushkevich, L.V., 1947. Equation of the characteristic curve of activated charcoal. Chem Zent. 1 (1), 875.

Emamjomeh, M.M., Sivakumar, M., 2009. Review of pollutants removed by electrocoagulation and electrocoagulation/ flotation processes. J. Environ. Manage. 90(5), 1663-1679.

Ezechi, E.H., Isa, M.H., Kutty, S.R.M., Yaqub, A., 2014. Boron removal from produced water using electrocoagulation. Process Saf. Environ. Prot. 92, 509-514.

Flilissa, A., Méléard, P., Darchen, A., 2013. Selective removal of dodecylsulfate during electrolysis with aluminum electrodes. Desalination and Water Treatment, 51(34-36), 67196728 .

Freundlich HMF., 1906. Uber die adsorption in losungen, Z Phys. Chem. 57A, 385-470. 
Fukui, Y., Yuu, S., 1985. Removal of colloidal particles in electroflotation. AIChE J. 31, $201-208$.

Ghaemi, M., Absalan, G., 2014. Fast removal and determination of doxycycline in water samples and honey by Fe3O4 magnetic nano particles. J Iran Chem. Soc. 12, $1-7$.

Ge, J., Qu, J., Lei, P., Liu, H., 2004. New bipolar electrocoagulation-electroflotation process for the treatment of laundry wastewater. Sep. Purif. Technol. 36, 33-39.

Ghernaout, D., Ghernaout, B., Saiba, A., Boucherit, A., Kellil, A., 2009. Removal of humic acids by continuous electromagnetic treatment followed by electrocoagulation in batch using aluminum electrodes. Desalination 239, 295-308.

Glembotskii, V.A., Mamakov, A.A., Ramanov, A.M., Nenno, V.E., 1975. Proceedings of the 11th International Mineral Processing Congress, Cagliari, Italy, pp. 562-581.

Hassan, S. A., Ali, F. J., 2014. Equilibrium, thermodynamics and kinetics study of doxycycline adsorption from aqueous solution using spent black tea leaves and pomegranate peel wastes. Int. J Development Res. 4(1), 129-135.

Ho, Y.S., Wase, D.A.J., Forster, C.F., 1996. Kinetic studies of competitive heavy metal adsorption by sphagnum moss peat. Environ.Technol. 17, 71-77.

Janpoor, F., Torabian, A., Khatibikamal, V., 2011. Treatment of laundry wastewater by electrocoagulation. J. Chem. Technol. Biotechnol. 86, 1113-1120.

Ji, L., Chen, W., Duan, L., Zhu, D., 2009. Mechanisms for strong adsorption of tetracycline to carbon nano tubes: a comparative study using activated carbon and graphite as adsorbents. Environ. Sci. Technol. 43, 2322-2327.

Kamaraj, R., Vasudevan, S., 2015. Evaluation of electrocoagulation process for the removal of strontium and cesium from aqueous solution. Chemical Engineering Research and Design. $93,522-530$. 
Karickhoff, S.W., 1981. Semi-empirical estimation of sorption of hy drophobic pollutants on natural sediments and soil, Chemosphere, 10, 833-846.

Kashefialas, M., Khosravi, M., Marandi, R., Seyyedi, K., 2006. Treatment of dye solution containing colored index acid yellow 36 by electrocoagulation using iron electrodes.Int. J. Environ. Sci. Technol. 2, 365-371.

Khan, M.H., Bae, H., Jung, J.Y., 2010. Tetracycline degradation by ozonation in the aqueous phase: proposed degradation intermediates and pathway. J. Hazard. Mater. 181, 659-665.

Lagergren, S., 1898. About the theory of so-called adsorption of soluble substances. Handlingar, Band 24, No. 4, 1-39.

Lakshmi, J., Sozhan, G., Vasudevan, S., 2013. Recovery of hydrogen and removal of nitrate from water by electrocoagulation process. Environ. Sci. Pollut. Res. 20, 2184-2192.

Langmuir, I., 1916. The constitution and fundamental properties of solids and liquids, J Amer. Chem. Soc. 38, 2221-2295.

Liu, Y., Gan, X., Zhou, B., Xiong, B., Li, J., Dong, C., Bai, J., Cai, W., 2009.

Photoelectrocatalytic degradation of tetracycline by highly effective $\mathrm{TiO} 2$ nanopore arrays electrode. J. Hazard. Mater. 171, 678-683.

Malakootian, M., Mansoorian, H.J., Moosazadeh, M., 2010. Performance evaluation of electrocoagulation process using iron-rod electrodes for removing hardness from drinking water. Desalination 255, 67-71.

Maliyekkal, S.M., Anshup, Antony, K.R., Pradeep, T., 2010. High yield combustion synthesis of nano magnesia and its application for fluoride removal. Sci. Tot. Environ. 408, 2273 - 2283.

Merzouk, B., Gourich, B., Sekki, A., Madani, K., Vial, Ch., Barkaoui, M., 2009. Studies on the decolorization of textile dye wastewater by continuous electrocoagulation process. Chem. Eng. J. 149, 207-214.

Murphy, A.P., 1991. Chemical removal of nitrate from water. Nature, 350, $223-225$. 
Newcombe, G., Hayes, R., Drikas, M., 1993. Granular activated carbon: importance of surface properties in the adsorption of naturally occurring organics. Colloids Surfaces A: Physicochem. Eng. Aspects, 78, 65-71.

O’Connor, S., Aga, D.S., 2007. Analysis of tetracycline antibiotics in soil: advances in extraction, clean-up, and quantification. TrAC-Trend. Anal. Chem. 26, 456-465.

Ouaissa, Y.A., Chabani, M., Amrane, A., Bensmaili, A., 2014. Removal of tetracycline by electro - coagulation: Kinetic and isotherm modeling through adsorption. J. Environ. Chem. Eng. 2,177-184.

Parolo, M.E., Avena, M.J., Savini, M.C., Baschini, M.T., Nicotra, V., 2013. Adsorption and circular dichroism of tetracycline on sodium and calcium-montmorillonites. Colloids and Surfaces A: Physicochem. Eng. Aspects 417,57-64.

Reyes, C., Fernandez, J., Freer, J., Mondaca, M.A., Zaror, C., Malato, S., Mansilla, H.D., 2006. Degradation and inactivation of tetracycline by $\mathrm{TiO}_{2}$ photocatalysis. J. Photochem. Photobiol. A: Chem. 184, 141-146.

Sivasankar, V., Murugesh, S., Rajkumar, S., Darchen, A., 2013. Cerium Dispersed in Carbon (CeDC) and its adsorption behavior: A first example of tailored adsorbent for fluoride removal from drinking water. Chem. Eng. J, 214, $45-54$.

Swain, S.K., Dey, R.K., Islam, M., Patel, R.K., Jha, U., Patnaik, T., Airoldi, C., 2009. Removal of fluoride from aqueous solution using aluminum-impregnated chitosan biopolymer. Sep. Sci. Technol.44,2096-2116.

Tchomgui-Kamga, E., Audebrand, N., Darchen, A., 2013. Effect of co-existing ions during the preparation of alumina by electrolysis with aluminum soluble electrodes: Structure and defluoridation activity of electro-synthesized adsorbents. J Hazard. Mater. (254-255), $125-133$. 
Teng-Shih, Zin-Bou Liu, 2006. Thermally formed oxide on aluminium and magnesium. Materials Trans. 47, $1347-1353$.

Tsai, W.-H., Huang, T.-C., Chen, H.-H., Huang, J.-J., Hsue, M.-H., Chuang, H.-Yi., Wu, Y.-W., 2010. Determination of tetracyclines in surface water and milk by the magnesium hydroxide Co-precipitation method. J. Chromatogr. A 1217, 415-418.

Wan, Y., Bao, Y., Zhou, Q.X., 2010. Simultaneous adsorption and desorption of cadmium and tetracycline on cinnamon soil. Chemosphere $80,807-812$.

Wang, Y.-J., Jia, D.-A., Sun, R.-J., Zhu, H.-W., Zhou, A.-M., 2008. Adsorption and co-sorption of tetracycline and copper(II) on Montmorillonite as affected by solution pH. Environ. Sci. Technol. 42, 3254-3259.

Weber, W.J., McGinley, P.M., Katz, L.E., 1992. A distributed reactivity model for sorption by soils and sediments. 1. Conceptual basis and equilibrium assessments, Environ. Sci. Technol. 26, 1955-1962.

Weber Jr., W.J., Morris, J.C., 1963. Kinetics of adsorption on carbon from solution. J. Sanitary Eng. Div. Proceed. Am. Soc. Civil Eng. 89, 31-59.

Xiao-hong, G., Guang-hao, C., Chii, S., 2007. ATR-FTIR and XPS study on the structure of complexes formed upon the adsorption of simple organic acids on aluminum hydroxide. $\mathrm{J}$ Env. Sci. $19,438-443$.

Xiao, F., Wang, S., Xu, L., Wang, Y., Yuan, Z., Jia, Y., 2015. Adsorption of monothioarsenate on amorphous aluminum hydroxide under anaerobic conditions. Chem. Geol. (407-408), 4653. 
Yang, S., Cha, J., Carlson, K., 2005. Simultaneous extraction and analysis of 11 tetracycline and sulfonamide antibiotics in influent and effluent domestic wastewater by solid-phase extraction and liquid chromatography-electrospray ionization tandem mass spectrometry. J Chromatogr A $1097,40-53$.

Yavuz, Y., Öcal, E., Koparal, A.S., Öğütveren, Ü.B., 2011. Treatment of dairy industry wastewater by EC and EF processes using hybrid Fe-Al plate electrodes. J. Chem. Technol. Biotechnol. 86, 964-969.

Zaidi, S., Chaabane, T., Sivasankar, V., Darchen, A., Maachi, R., Msagati, T.A.M., 2015. Electro-coagulation coupled electro-flotation process: Feasible choice in doxycycline removal from pharmaceutical effluents. Arab. J Chem. doi: 10.1016/j.arabjc.2015.06.009.

Zhang, Z., Sun, K., Gao, B., Zhang, G., Liu, X., Zhao, Y., 2011. Adsorption of tetracycline on soil and sediment: effects of $\mathrm{pH}$ and the presence of $\mathrm{Cu}$ (II). J. Hazard. Mater. 190, 856-862.

Zhou, Y., Liang, Z., Wang, Y., 2008. Decolorization and COD removal of secondary yeast wastewater effluents by coagulation using aluminum sulfate. Desalination 225, 301-311.

Zhao, Y., Geng, J., Wang, X., Gu, X., Gao, S., 2011. Adsorption of tetracycline onto goethite in the presence of metal cations and humic substances. J Colloid Inter Sci. 361, 247-251.

Zhao, Y., Gu, X., Gao, S., Geng, J., Wang. X., 2012. Adsorption of tetracycline (TC) onto montmorillonite: Cations and humic acid effects. Geoderma, 183-184, 12-18.

Zhao, Y., Tong, F., Gu, X., Gu, C., Wang, X., Zhang, Y., 2014. Insights into tetracycline adsorption onto goethite: Experiments and modeling. Sci. Tot. Environ. 470-471, 19-25. 
Fig. 1 Schematic experimental set up of Electro-coagulation coupled Electro-flotation system and pilot type EC - EF treatment system used in the laboratory (insert at top right)

Fig. 2 Removal of DCH as a function of current density (A) $\mathrm{pH}$ of the solution (B) initial DCH concentration (C) and interfering ions (D)

Conditions: A) $p H=7,[D C H]=100 \mathrm{mg} \mathrm{L}^{-1}, Q=52 \mathrm{~L} \mathrm{~min}^{-1}, d=1 \mathrm{~cm}$, Conductivity $=1.78 \mathrm{mS}$ $\mathrm{cm}^{-1}$

B) $[D C H]=100 \mathrm{mg} \mathrm{L}^{-1}, C D=5.39 \mathrm{~mA} \mathrm{~cm}^{-2}, Q=52 \mathrm{~mL} \mathrm{~min}^{-1}, d=1 \mathrm{~cm}$, Conductivity $=1.78 \mathrm{mS} \mathrm{cm}^{-1}$

$m S \mathrm{~cm}^{-1}$

C) $\mathrm{pH}=7, \mathrm{CD}=5.39 \mathrm{~mA} \mathrm{~cm}^{-2}, Q=52 \mathrm{~mL} \mathrm{~min}^{-1}, d=1 \mathrm{~cm}$, Conductivity $=1.78$

D) $p H=7,[D C H]=100 \mathrm{mg} \mathrm{L}^{-1}, C D=5.39 \mathrm{~mA} \mathrm{~cm}^{-2}, Q=52 \mathrm{~mL} \mathrm{~min}^{-1}, d=1 \mathrm{~cm}$

Fig.3 DCH sorption onto EGA as a function of solution $\mathrm{pH}(\mathrm{A})$ initial DCH concentration (B) electrolyte $(\mathrm{C})$

Conditions : $[D C H]=100 \mathrm{mg} \mathrm{L}^{-1} ;$ EGA dose $=1 \mathrm{~g} \mathrm{~L}^{-1} ;$ Contact time $=150 \mathrm{~min}$; Temperature $=288 \mathrm{~K}$

$$
[D C H]=100 \mathrm{mg} \mathrm{L}^{-1} ; \mathrm{pH}=3.5 \pm 0.05 ; \text { EGA dose }=4 \mathrm{~g} \mathrm{~L}^{-1} ; \text { Contact time }=150
$$

min $;$ Temperature $=288 \mathrm{~K}$

$$
[D C H]=100 \mathrm{mg} \mathrm{L}^{-1} ; \mathrm{pH}=3.5 \pm 0.05 ; E G A \text { dose }=4 \mathrm{~g} \mathrm{~L}^{-1} ; \text { Contact time }=150
$$

min $;$ Temperature $=288 \mathrm{~K}$

Fig. $4 \mathrm{X}$ - ray diffraction pattern of EGA (A) and EC - EF generated and DCH trapped $\mathrm{Al}(\mathrm{OH})_{3}$ flocs (D) powdered EGA adsorbent (B) Scanning electron micrographs of EGA (C) and EC - EF generated $\mathrm{Al}(\mathrm{OH})_{3}$ flocs $(\mathbf{E})$ 


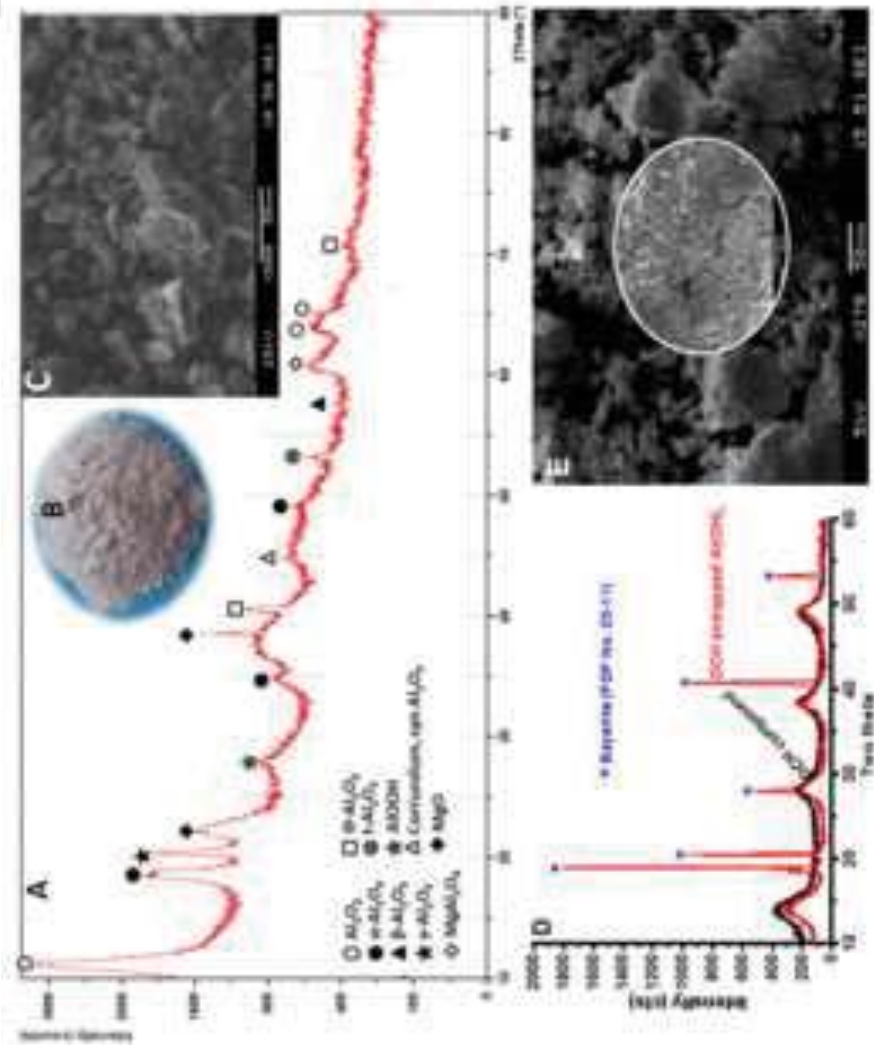




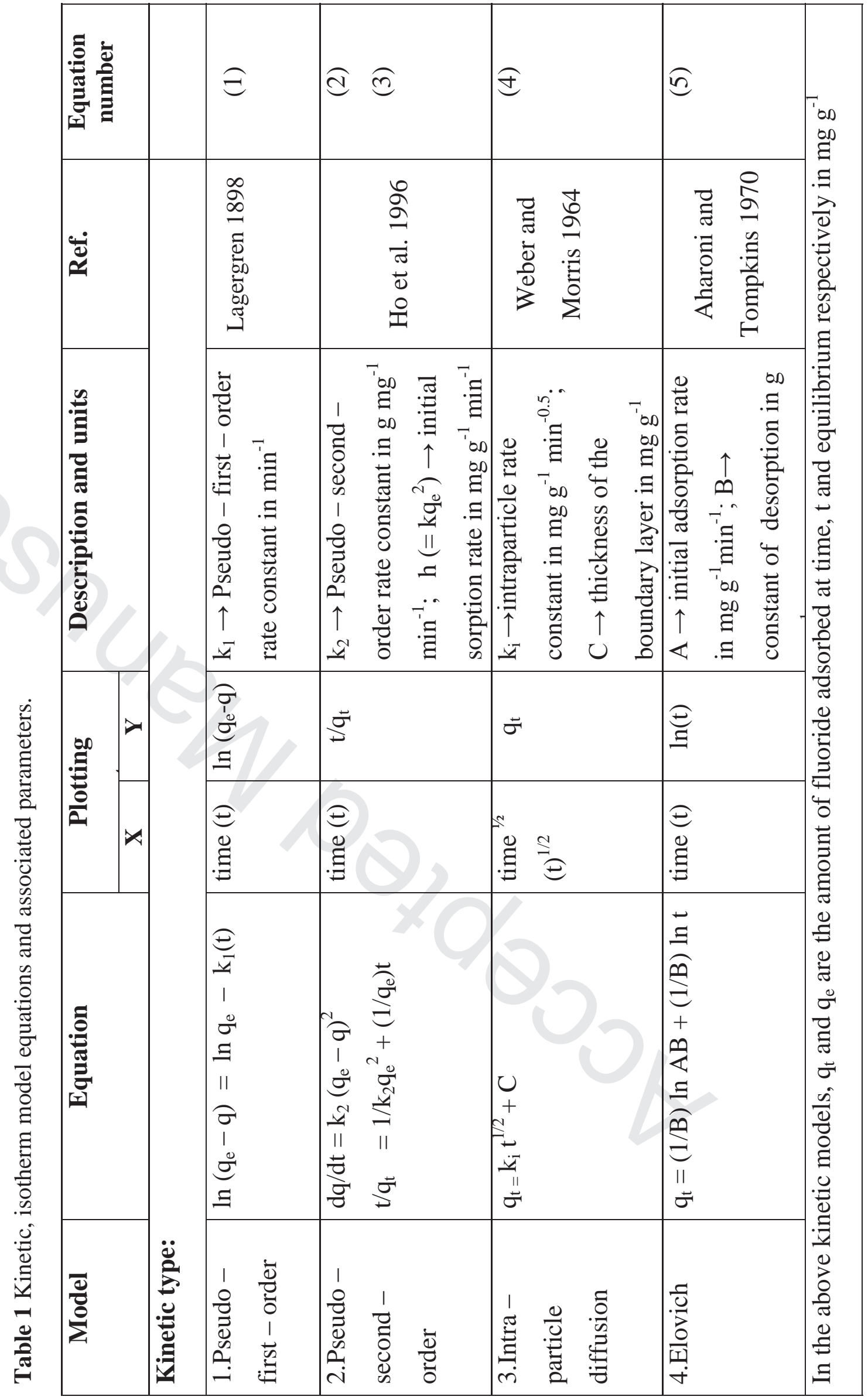




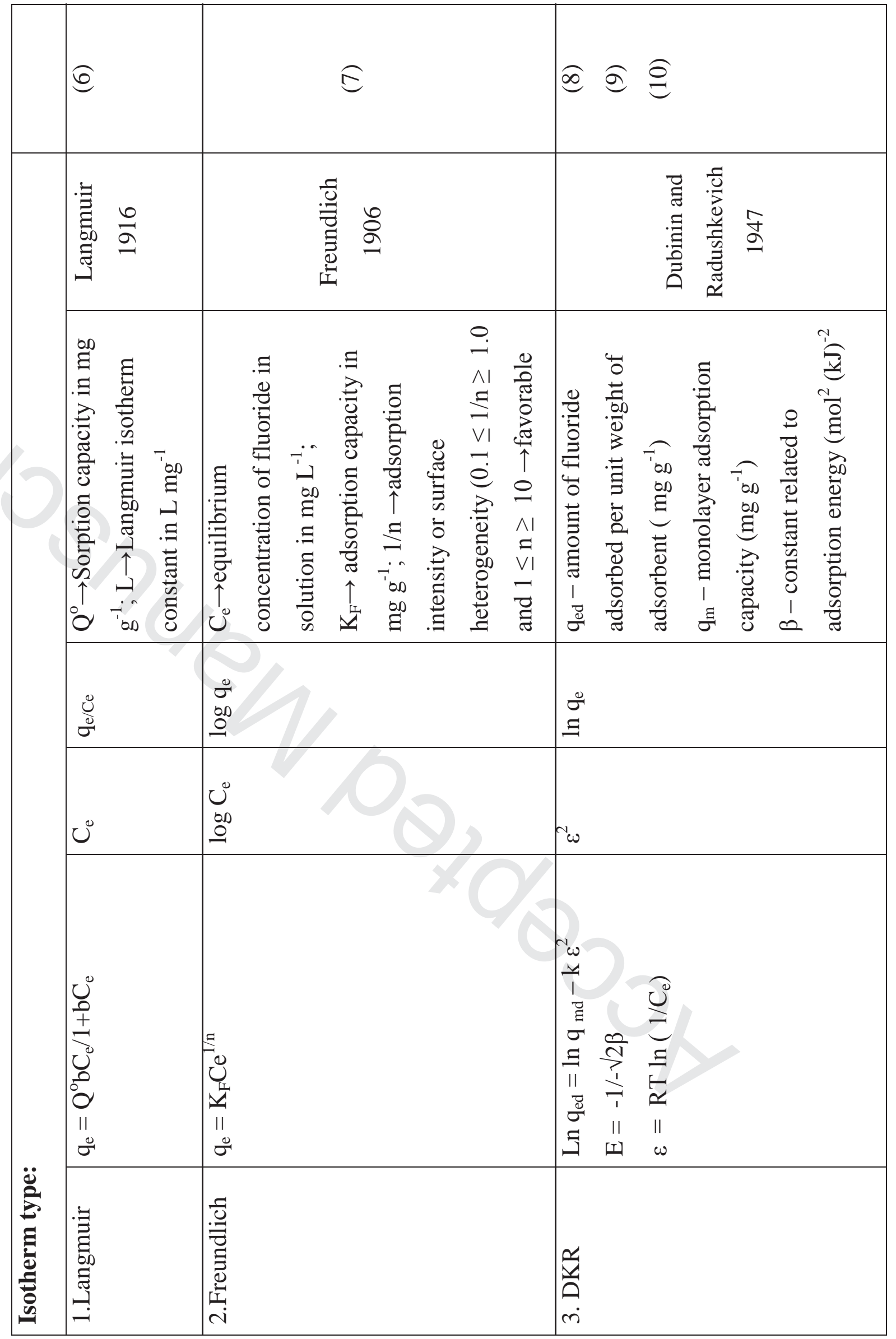




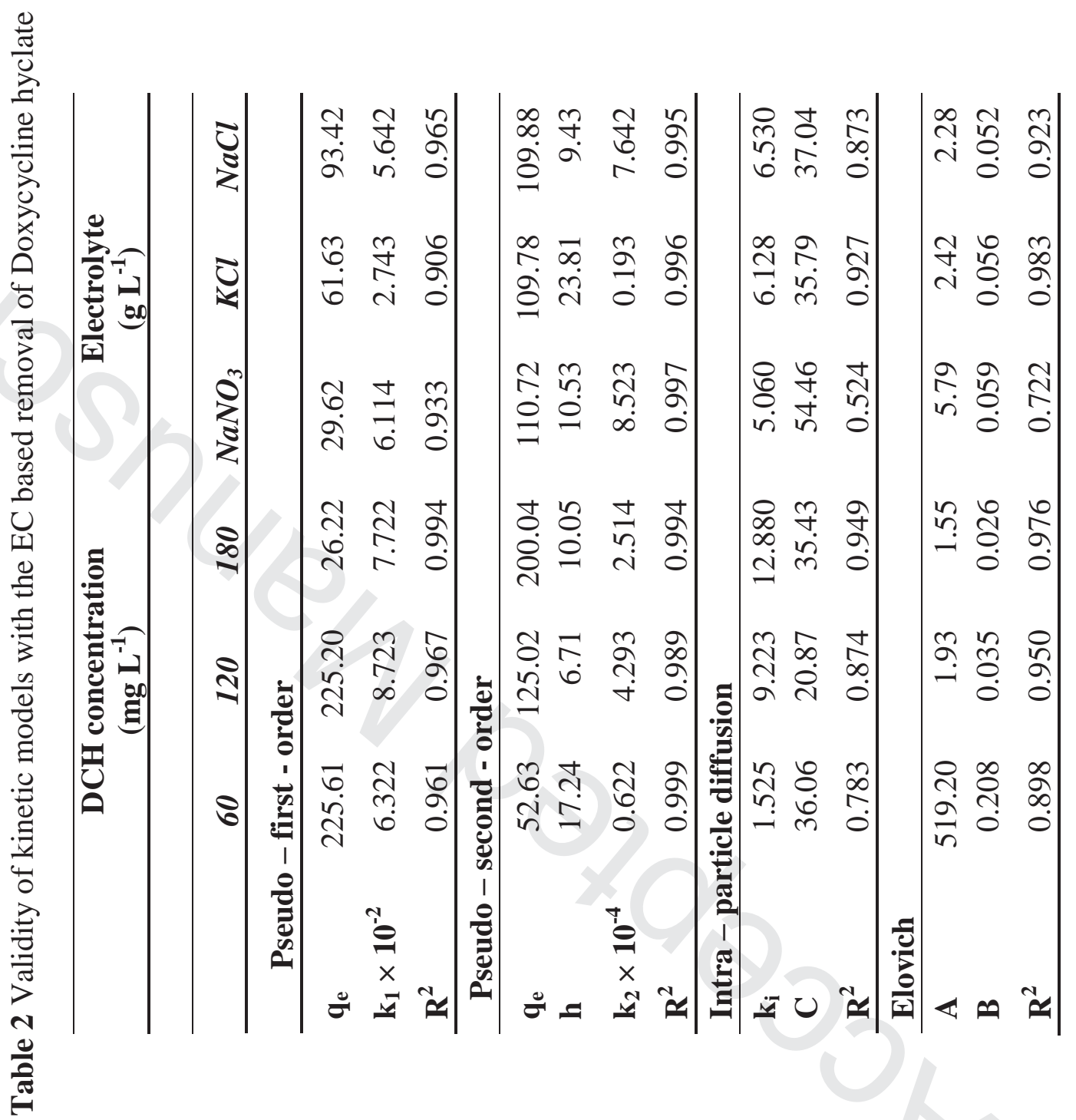




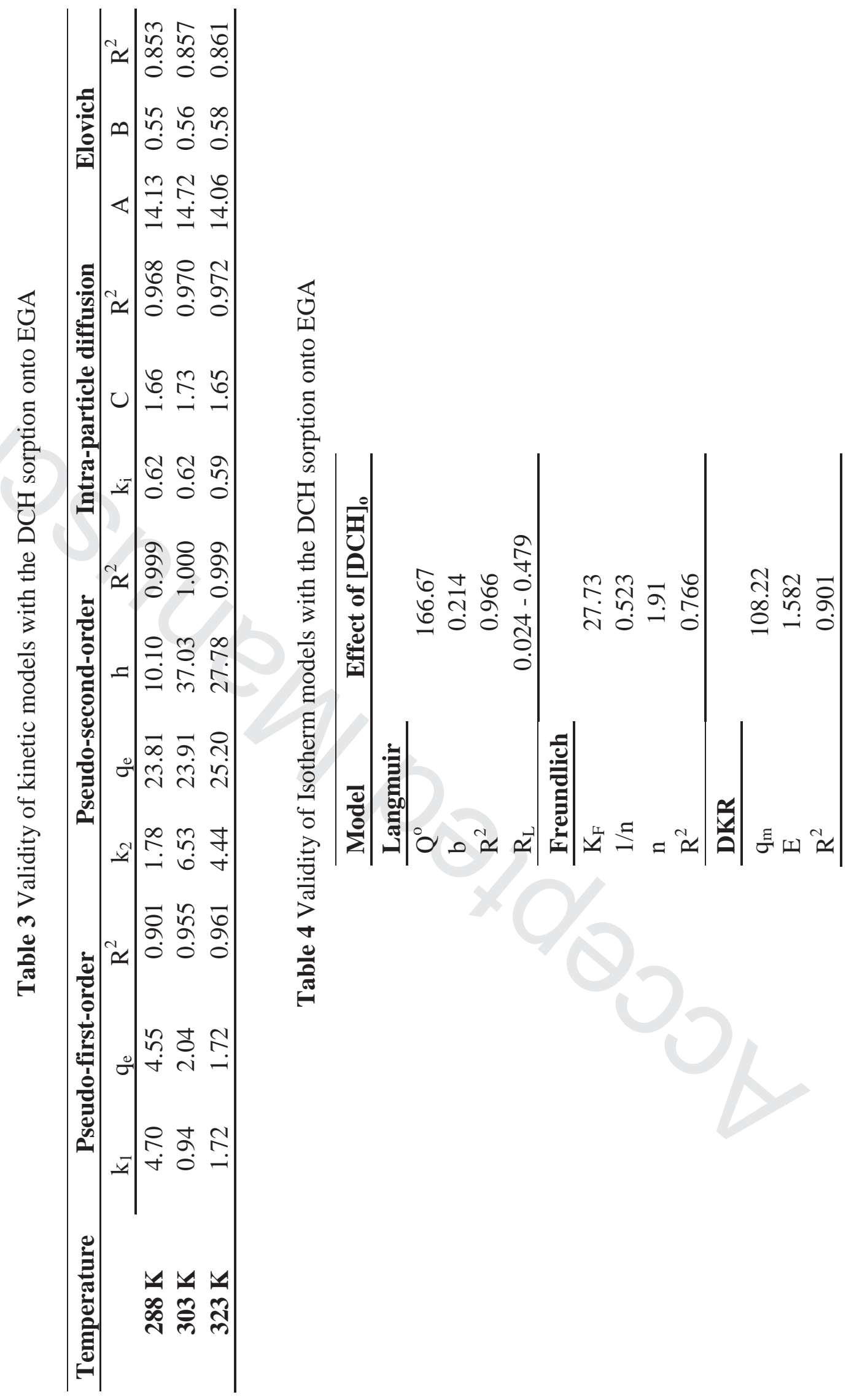




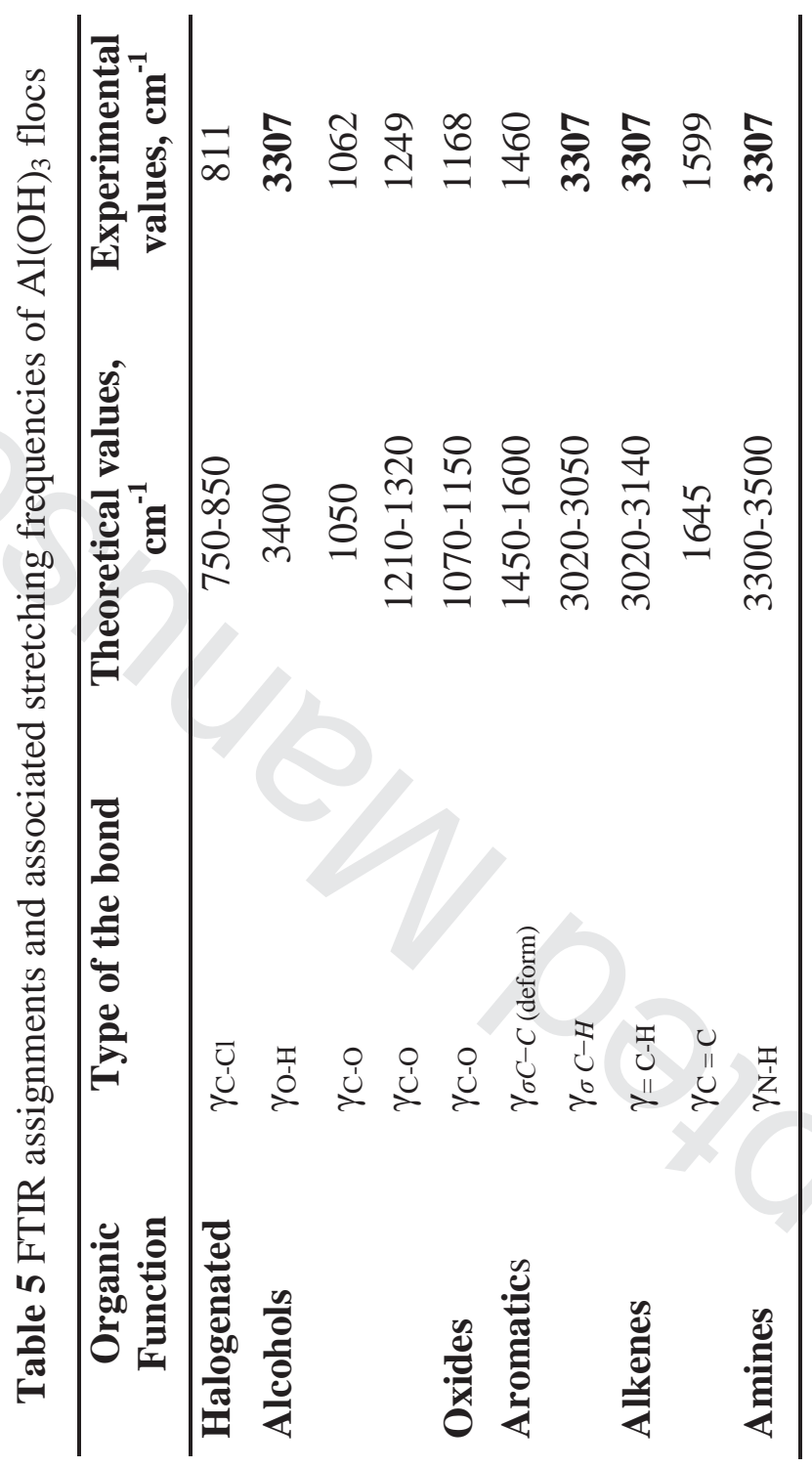




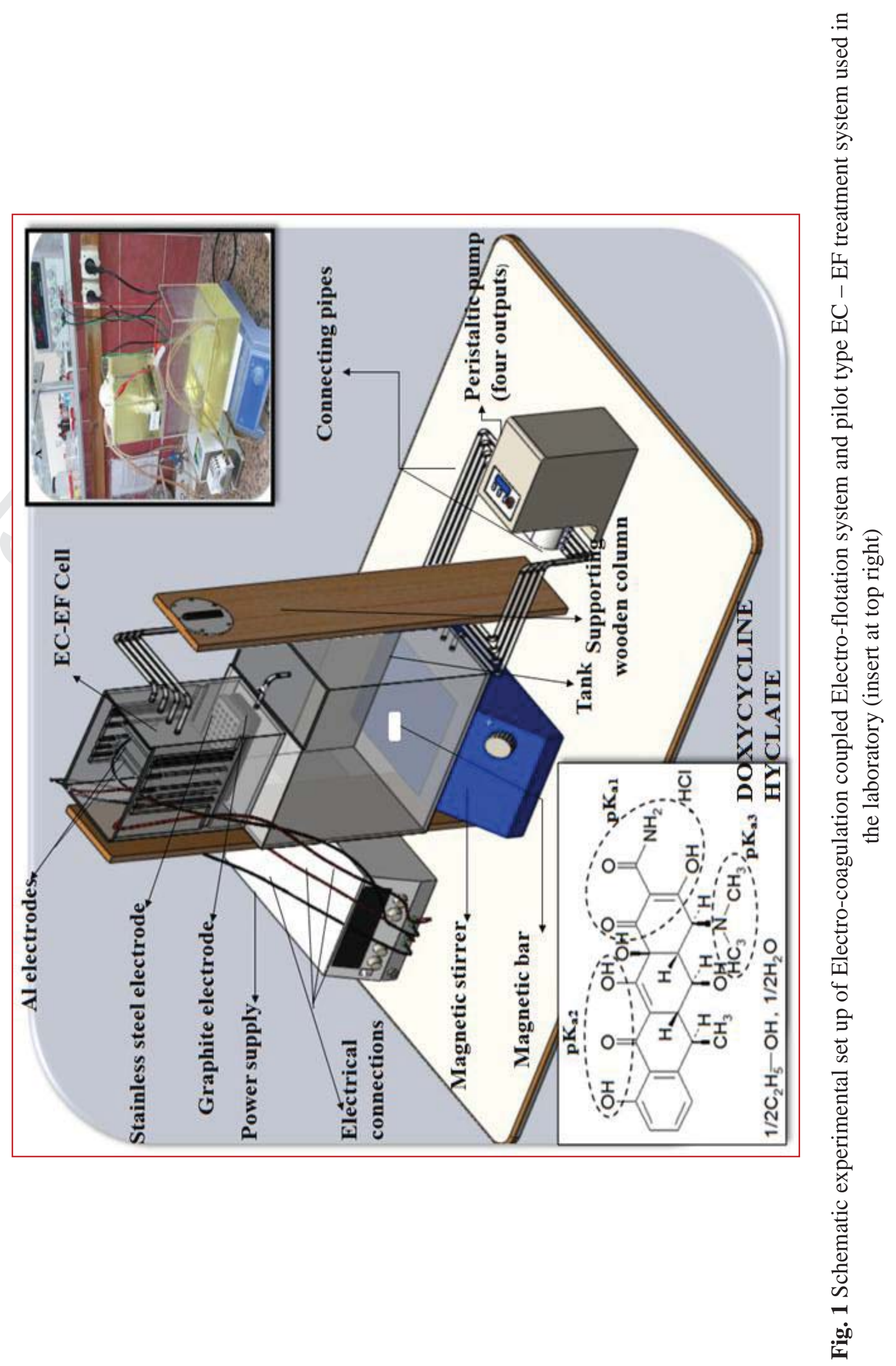




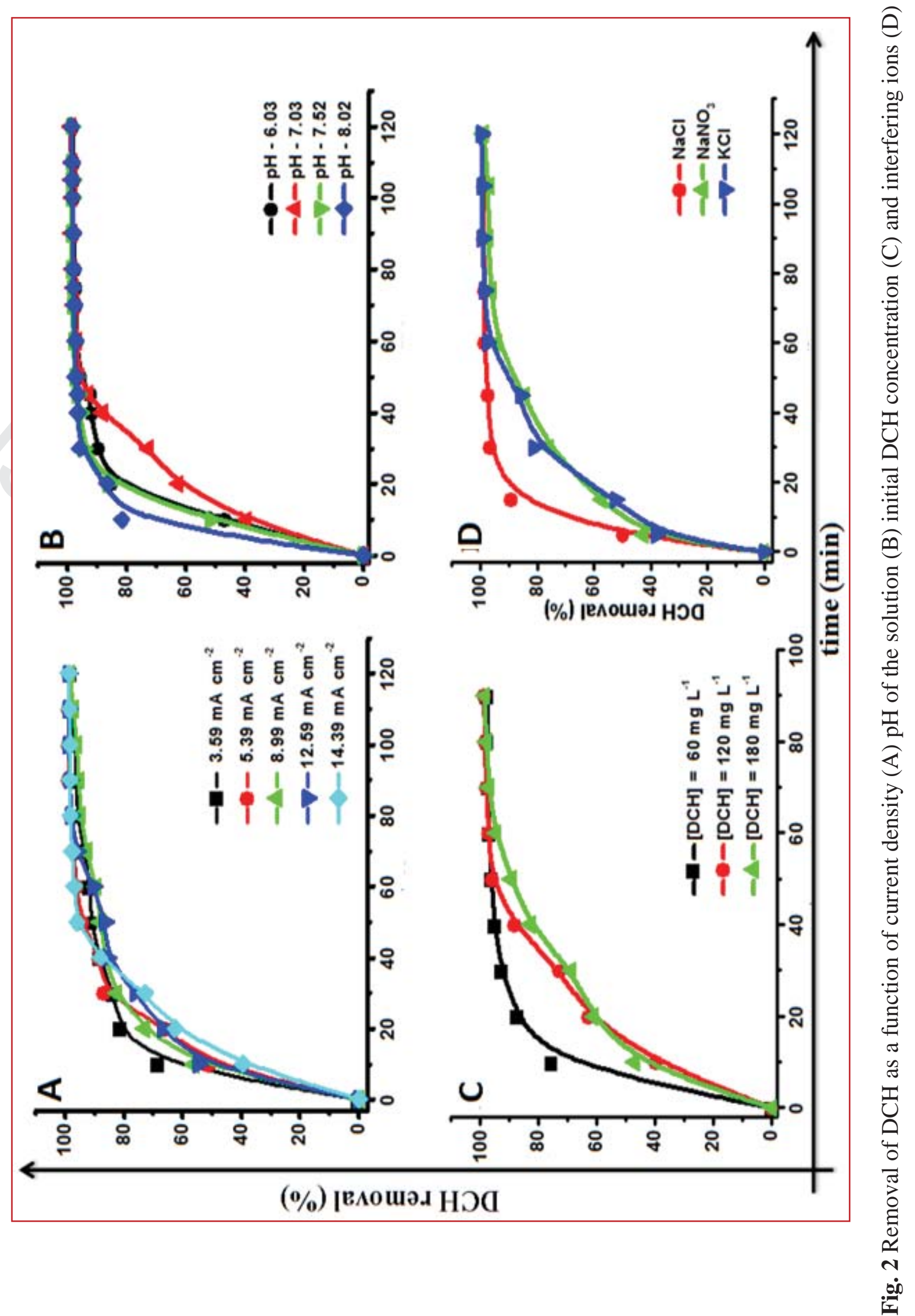





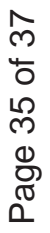

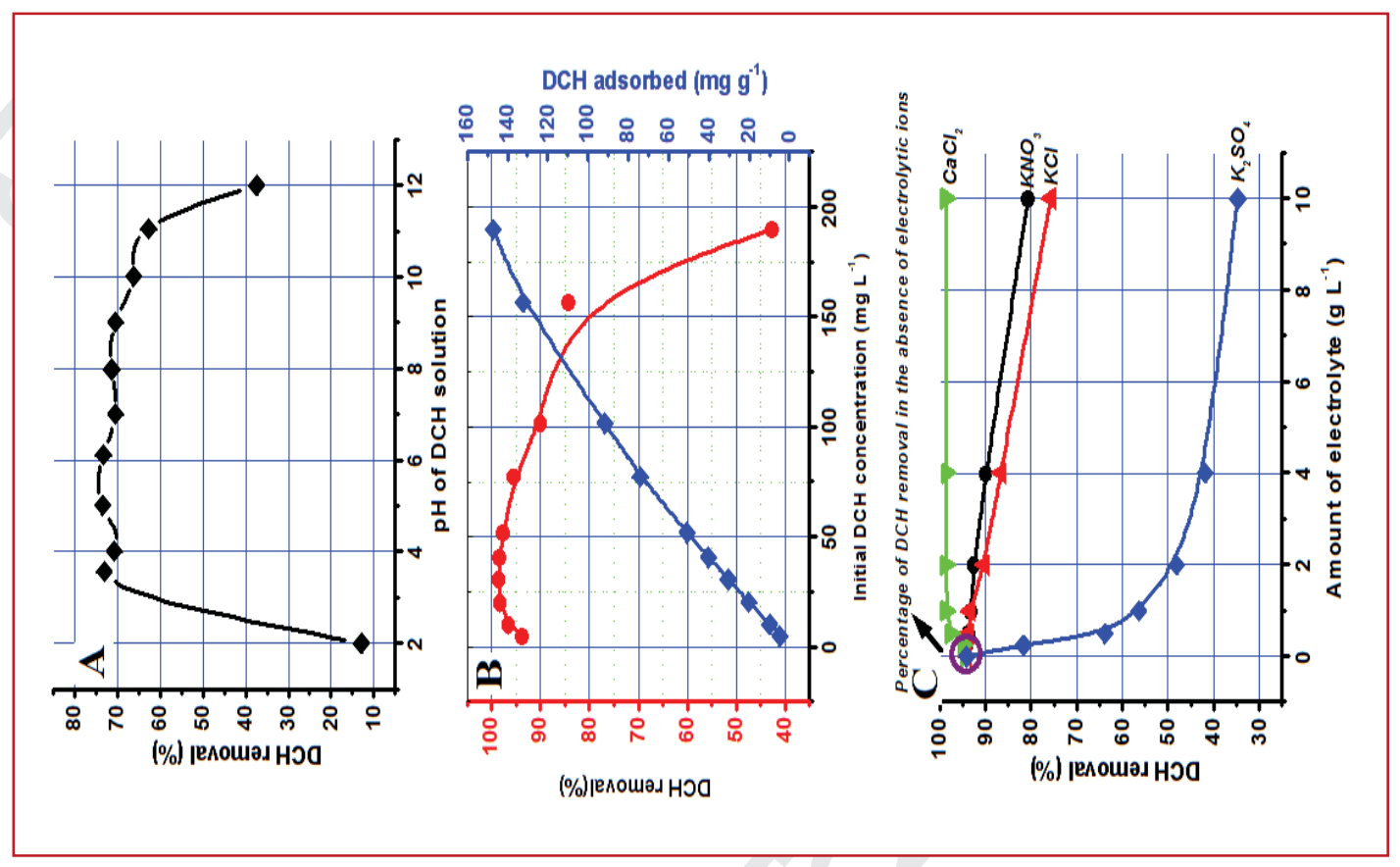

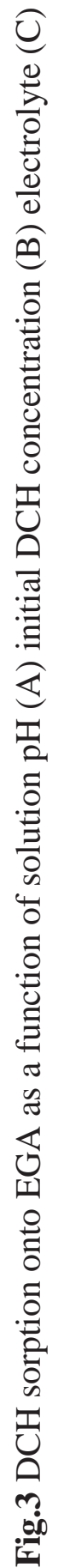



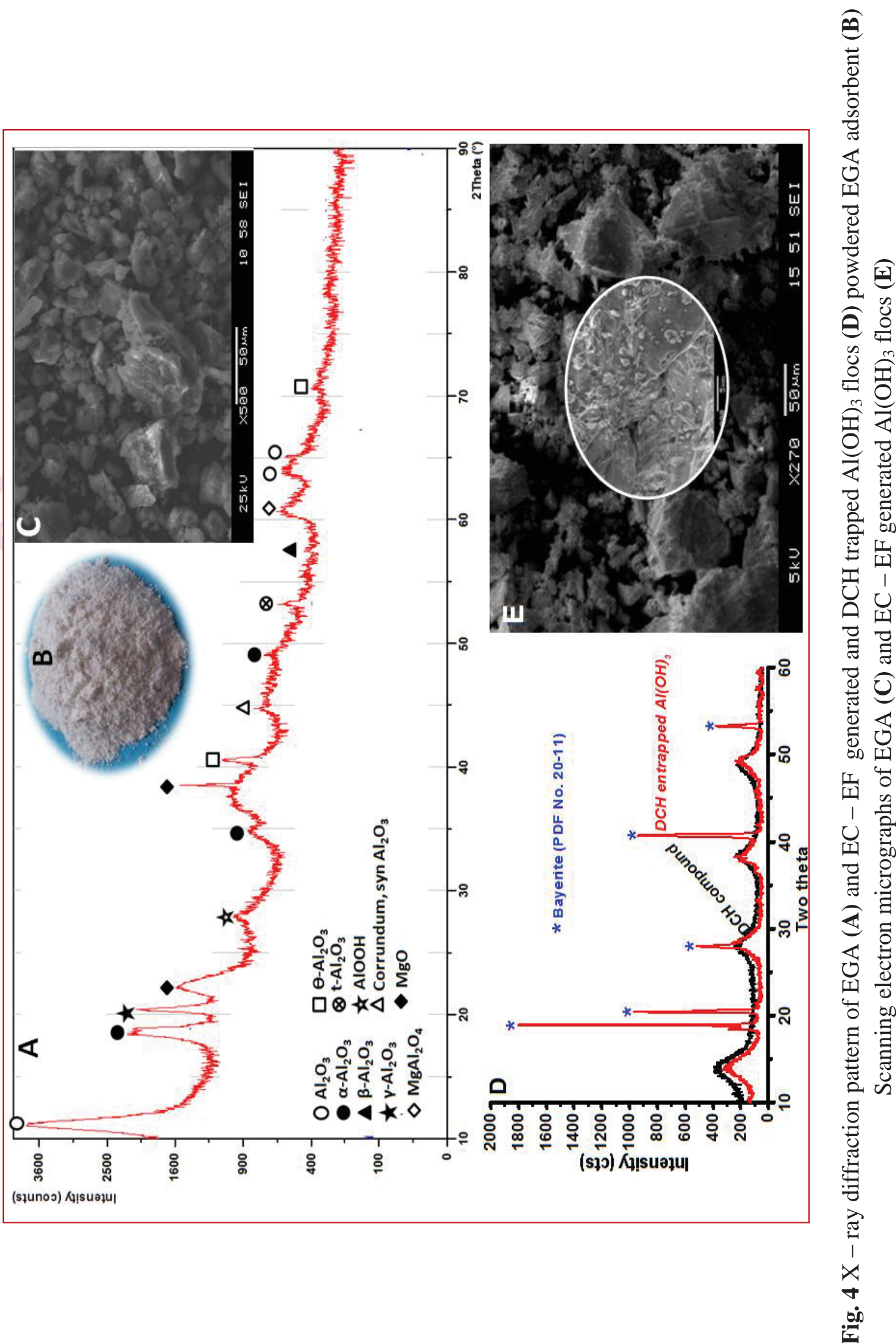